\title{
THE EFFICIENCY OF CALCULATING THE COSTS THROUGH ORDER METHOD IN THE FURNITURE INDUSTRY - CASE STUDY
}

\author{
Radu MARGINEAN ${ }^{1}$
}

\begin{abstract}
Furniture industry represents the most efficient and profitable form of superior capitalization of wood, having the greatest added value in the wood processing industry. In this paper we make a motion for presenting the method of calculating costs per order and its positioning as compared to other methods of managing the costs, as well as applying the method in a big entity in wood industry in Romania. The case study presents entirely the appliance of the method of calculating costs per order and aims to conclude its efficiency in the costs' management process in the Romanian wood industry. We opine that despite the fact that the method of calculating costs per order is a classical one, having certain assumed limits it has a special utility in the sector due to the activity's specifics of furniture manufacturing. By applying the method per order in the wood industry from Romania, a good run-down and integration is made concerning the expenses incurred by manufacturing, as well as their reflection in a trusty way in the managerial accounting.
\end{abstract}

Key words: furniture industry, managerial accounting, accounting cost, accounting, case study

Jel Codes: M40, D24, M41

\section{Introduction}

Analyzing the structure and management of furniture industry in Romania, we could ascertain that the most entities in this sector are of rather small dimension, approximately three quarters of them having fewer than 10 employees. (Radu Mărginean, 2015). The Economical - financial performance represents a main desideratum, an adamant purpose in the entities' management in economy in general, and from the furniture industry in Romania in particular. Romania has to grant an increasing attention to the furniture industry, because this represents the wood's superior form of capitalization, having the biggest added value. The interest is as higher as the talks concerning the illegal forest clearing in Romania are of high relevance. A phenomenon's reduction is wished, context in which we infer the opportunity and the importance of sustaining the furniture producers in Romania.

Sustaining the small and medium sized enterprises in general in economy, may undertake many different forms. Concerning the furniture industry, we consider that a necessary effort with immediate impact would be the computerization of manufacturing processes with the purpose of obtaining more data having the capacity of sustaining the managerial decision making process. We consider useful such a process, in the context in which the information technology facilitates nowadays the obtaining of some information which is extremely important and relevant for the entity.

The process of making the managerial decisions is mainly based on two information sources: financial accounting and managerial accounting or managing accounting. The information that he stakeholders receive from both of the systems are complementary, meant to complement a complex informational picture, a reporting base in the process of making the managerial decisions.

Managerial accounting, though not being mandatory for the entities, brings a huge informational plus. The approach of financial accounting may be considered rather a rigid one in

1 „1 Decembrie 1918” University, Alba-Iulia, Alba Iulia, radu.marginean@uab.ro

DOI: 10.29302/oeconomica.2019.21.1.2 
sustaining the management problem, concerning the process of making the managerial decisions, especially for entities having manufacturing activities, for which reason, the management accounting comes as a completion.

A first objective for research in the paper consists in evaluating the possibility of implementing the method of calculating costs per order in the furniture industry, actually applying the method in a case study based on real data, therefore offering the possibility of emitting appreciations concerning its efficiency in the furniture sector of this industry.

\section{Research Method}

The research we have made belongs to the economical domain, combining the theoretical methodological approach with the practically - applicable one. The scientific approach was based both on revising the specialty literature as well as on making a case study.

In the case of the first research objective, it was grounded on the specialty literature in the domain of the managerial accounting, as well as on legislation in effect in Romania concerning the management accounting.

The main research objective consisted in making a calculation of costs using the method per order, observing the applicability of the method, together with the pointing out its efficiency for the sector of furniture manufacturing in Romania. For reaching the research objectives we have followed the presentation of principles of the method of calculating costs per order, applying the method of calculation of costs through the method per order, specific staging, accounting the expenses in the managing accounting and making the necessary verifications concerning the closure of costs.

For the case study, a specific methodology has been used, a process of documentation being done at the headquarter of an entity from the sector of furniture industry at large scale, there have been consulted certain analyses made together with the managers, manufacturing process, thus benefiting from a comprehensive picture of the economical phenomenon reflected in the entity's activity.

Within the paper, of reasoning which pertain to the confidentiality of the internal data from the management accounting, we will not mention the name of the entity where the data come from, but we emphasis on the fact that the data are real. We can state that the studied entity is one of the most important in Romania, of large dimensions in the profile sector, having more than 500 employees and sales on the internal market and also internationally. In this regard, the society will be generic named SC. Alfa SRL.

\section{Literature Review}

The accounting in the Romanian national sector is generic divided into two broad ranges, namely, financial accounting and management or managerial accounting (Accounting Law, 1991). Management accounting, according to the legislation in effect is not mandatory for the Romanian entities, even though, in our opinion, it is indispensable for the entities having manufacturing activities. In our paper we will use both the notion of management accounting as well as the notion of managerial accounting.

The main difference between the two rages of accounting is mainly represented by the receiver of the final information. Financial accounting is orientated towards the exterior of the entity because it reflects the transposition of the entity's economical operations into the national accounting, reflecting the accounting amounts in the national accounts plan, thus offering the possibility of making the entity's financial statements. Certainly, the financial accounting offers pieces of information which are extremely important for analyzing the entities' economical performance, thing also confirmed by IAS 1, "Presenting financial statements, "the objective of the general financial statements is that of offering

information about an entity's financial position, performance and cash flow, useful for a wide range of users while making economical decisions" (IAS 1, point 7).

Managerial or managing accounting is inward oriented, having as a main purpose the sustaining of managerial decisions, following the improvement of the entity's activity, for maximizing the profit. From this perspective, the analyses effected based on the managerial accounting are destined only to the entity's board of directors, most of the times, the resulted information being used strictly inside the entity, its dissemination being forbidden.

Charles Horngren outlines the image concerning costs circulation through the fact that he mentions three 
accounting approaches. (Charles Horngren et. al, 2006): Financial accounting (outward oriented), management accounting (inward reported) and cost accounting. Cost accounting is described by the author as being positioned amongst the first two categories and appears to be a link between the two approaches.

The utility of the management accounting also results from its functions presented by Sorin Briciu, also presented in the legislation in effect, which basically are (Sorin Briciu, 2011): forward looking function, analytical registration function, control and comparative analysis function of production level and structure and of costs being calculated based on these two and informing function. According to the legislation in effect,

Order 1826/22.12.2013 for approving the stipulations concerning certain measurements referring to the organization and keeping the managerial accounting, in management accounting the costs are classified in(Order 1826, 2013, art.2): acquisition costs,

production costs, processing costs and costs of period.

In the specialty literature there are more methods of managing and analyzing costs, which theoretically may be applied to the furniture industry, each having strengths and weaknesses. Among the classical methods of cost calculation, approach and exemplifying in many places in the specialty literature we can refer to: global method, method per order and method per phase. These circulation methods are used in entities having industrialized production for many years and they represent an important calculation framework for big entities in the Romanian economy. The method per orders is also the most utilized method in the furniture industry for costs calculation. Among the modern methods of calculating costs, we state the ABC method (Activity-Based Costing), direct costing method, Standard costing method, Kaizen costing method or cost continuous managing and target costing method(Radu Mărginean, 2015).

For emphasizing certain advantages of the modern methods of calculating costs, in comparison with the classical method per orders, we will make a short describing of standard costing method, target costing and kaizen costing:

- standard costing method, method which used to be applicable in the furniture industry in Romania(Radu Mărginean, 2013). This is a part of the provisional costing methods and of operative following of the production process, allowing the establishment of production costs in anticipation from the beginning of production process. At the same time, the method allows performing a budgetary control by determining the distortions of effective costs as opposed to the pre-established ones, while realizing the production. A plus of this method to the classical method of costs calculation per order is the capacity of the standard costing method to operatively follow the production costs as they are registered(Cleopatra Sendroiu, 2006);

- target costing method, has as specification to standard costing the fact that in the budgeting process the market price is first taken into account, which consequently will give the final cost of the product(Radu Mărginean and Țepeş Bodescu Anamaria, 2014). In the specialty literature there are more ways of applying the method, and we recall the following staps: establishing the target cost according to the market context and of the competitive environment, establishing the target profit margin, determining the estimated and the target costs, calculating the estimated cost of products and of the estimated activities and calculating the amount with which the costs need to be adjusted/reduced (Sorinel Căpuşneanu and Briciu Sorin, 2011), therefore we observe that the capacity of the first two methods of controlling the production costs during the manufacturing process, comparing at a certain point the standard cost and target cost with the manufacturing process at the time, which offers an effective cost;

- kaizen costing method, is very similar with the target costing method. In contrast to the target costing method, which is used by the design staff before the production phase begins, the kaizen costing method is used by production staff during the product's manufacturing. The methods differ by their appliance: the target costing method starts from the customers' considerations, while the kaizen costing method is based on the profitability of the objectives imposed by the managers(Briciu Sorin et.al, 2010). Even if we have in this case a modern method of calculating the costs, its applicability in the furniture industry would have to be proven. In essence, specific to the production process in the furniture industry is mainly static and the adjustment of the direct costs during the production process would be extremely difficult;

According to the authors Briciu et.al.(2010) the classical method of calculating the costs "per order" is used within the industrial entities with individual or series production, with a complex manufacturing process, in which the final product, if taken separately is the result of mechanical combination of certain pieces, subassemblies, subsequently manufactured and packed. According to the mentioned authors, method is 
applicable in the machine building industry, furniture industry, clothing industry or electrical engineering industry. Specific to this method, the bearer of expenses is the order itself. The general method of calculating the intermediary products is as it follows(Briciu Sorin et.al, 2010):

where:

$$
\text { Ctotal }=\frac{\sum_{i=1}^{n} C h d i+\sum_{i=1}^{n} C h i}{q i}
$$

Ctotal $=$ total unit cost

Chdi = direct expenses

Chi $=$ indirect expenses

$q i=$ quantiy per unit of product

For the final product, the calculation of final cost will be the sum of the cost of the intermediary cost or of component parts as follows:

where:

$$
C t=c t 1+c t 2+\ldots+c t n+\sum C d a+\sum C i a,
$$

$C t=$ final product cost;

Ct1, ct2, ctn = component parts' cost;

$C d a=$ general direct expenses of assembley and finishing Cia $=$ general indirect expenses;

Indirect expenditure share is calculated based on a calculus coeficient $\mathrm{K}$, resulted from the formulae:

$$
K=\frac{\text { Total of indirect expenses at month level }}{\text { Total incomes of direct productive workers }}
$$

After calculating the $\mathrm{K}$ coefficient, the assignment is made for each order of indirect expenses, multiplying the $\mathrm{k}$ coefficient of expenses with reporting base per each order, most of times the total of direct productive workers' incomes.

In the method per orders, the calculation objective is constituted by the order placed in execution for a certain quantity of products, and practically any settlement document will have some information about the order to which that document belongs. The documents used in registering and managing the productions on which the series and order number will be marked are: the receipt, consumer limit sheet, work vouchers, scrap notes, release notes, etc. for each placed order, after calculation sheet will be distinctively held, sheets which may represent analytics for 921 account "Expenses for main activities". For each order direct expenses are cumulated, and at the end of the month these are added with the shares corresponding to the indirect expenses(Briciu Sorin et. Al, 2010). The scheme of cost calculation after the method per order is as it follows:

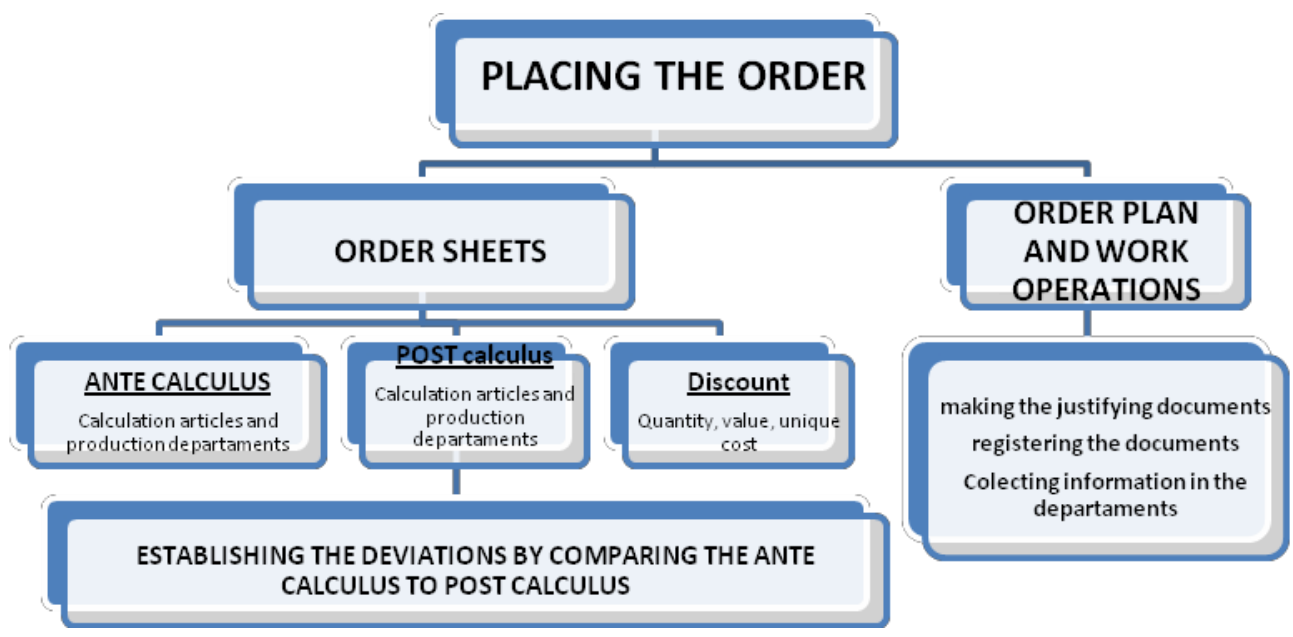




\section{Figure 1. The scheme of calculating costs through the method per order}

Source: processing after Briciu Sorin et. Al.(2010), p. 287

We specify that using the accounts in the management accounting is not mandatory, but for a complete presentation of cost calculation in the case study, we will present and use common accounts from the managerial accounting in Romania, as they are defined in the actual legislation(OMFP 1802/2014, art. 594):

901 "Internal settlements concerning expenses"

902 "Internal settlements concerning the obtained production" 903

"Internal settlements concerning price differences"

921 "Expenses of main activity"

922 "Expenses with auxiliary activities" 923

"Production indirect expenses"

924 "General administrative expenses" 925

"Selling expenses"

931 "The cost of obtained production" 933

"Cost of production in progress"

The method per order is limited through many elements, even if it allows a rigorous organization of calculating costs(Briciu sorin et. Al, 2010):

- it does not allow the determining of production cost only at the end of the whole order, and therefore there is the hypothesis according to which the operative following of the expenses might have a late character.

- within the same order it might exist the situation in which certain consumption of raw materials or materials to pass from a product to another, form an order to another, out of operating errors;

- partial settlement of orders concerning certain pieces may create the situation in which certain expenses to be made only by certain products, and not by all the order in tis whole.

\section{Case Study}

The order is registered on each and every product, products having different technical consumption norms, raw materials and goods, and norms concerning execution time. Technically, each order carries expenses and an entire production cycle, as stretching over time, might take more than a couple of months or a month, according to complexity, technical procedures, charging the machineries and production staff. Procedurally, concerning cost calculation, an production ante calculus and post calculus, and the steps are the following(Radu Mărginean, 2015):

- Each product has a normative consumption of raw materials and materials, based on which the necessary of materials per order is made;

- Each product has a time normative based on which manufacturing is loaded for the direct productive staff per each order.

- Based on the information concerning production expenses with materials and labor and based on the historical data concerning indirect expenses an approximate ante calculus of production cost is made.

- Based on the production data concerning the actual production expenses, the limit consumption sheets are given to the order accountants on each production section, which are then centralized at order level for their registration in the general post calculus sheet.

- If the production takes more than a couple of months, after the same month that the order was placed, the order's sheet of post calculus is opened. The post calculus sheet contains the monthly development of the elements of expenses on each and every order, starting from the number of products in the order and their monthly development.

- According to the facilities and other services received from the suppliers, but also to the real expenses occasioned by the production of those products, the actual cost of the order is going to be made, which will be compared with the estimated cost from the ante calculus, from where a favorable or unfavorable difference of the estimation will be observed.

For this case study we will present the production and calculation cycles through method per order in S.C. Alfa S.R.L. two orders for two products are received, orders which will be integrally produced during the 
following month, using the entire capacity of the implied section, namely Section 1 (S1) Preparation and Cutting, Section 2 (S2) Furniture and Section 3 (S3) Packing and storage of finished products. The two orders contain the following products:

- Order A: Product York Wardrobe - 20 wardrobes

- Order B: Product York Night Stand - 50 night stands.

For realizing the two orders, more expenses have been registered into accounting, which will be recorded in stages in the managerial accounting; therefore the closure of accounts will be made in the management accounting, each accounting note being numbered with the purpose that in the end the accounts closure may be followed.

Production activity occasioned the following distribution costs:

a) raw material consumption, total of receipts in amount of $38160 \mathrm{RON}$ :

- in section S1 18715 RON, of which for:

- order A $12145 \mathrm{RON}$;

- order B 6570 RON;

- in section S2 $10550 \mathrm{RON}$, of which for:

- order A 5050 RON;

- order B 5500 RON;

- in section S3 $8895 \mathrm{RON}$, of which for:

- order A 7545 RON;

- order B $1350 \mathrm{RON}$;

1. Registering the expenses with raw materials on sections and orders:

921 „Expenses with main activity” = 901 „Internal settlements concerning expenses”

$\underline{38160,00}$

921-S1-A

901-S1-A

901-S1-B

901-S2-A

901-S2-B

901-S3-A

901-S3-B
12145,00

6570,00

5050,00

5500,00

7545,00

1350,00

b) Expenses with direct incomes, a total of $21550 \mathrm{RON}$ :

- in section S1 10760 RON, of which for:

- order A 7560 RON;

- order B $3200 \mathrm{RON}$;

- in section S2 6610 RON, of which for:

- order A 5560 RON;

- order B 1050 RON

- in section S3 4180 RON, of which for:

- order A 3380 RON;

- order B $800 \mathrm{RON}$;

2. Registering the expenses with direct labor:

921 „Expenses of main activity” = 901 ,Internal settlements concerning exprnses”

921-S1-A

921-S1-B

921-S2-B

921-S2-B

921-S3-A

921-S3-B
901-S1-A

901-S1-B

901-S2-A

901-S2-B

901-S3-A

901-S3-B
21550,00

7560,00

3200,00

5560,00

1050,00

3380,00

800,00 


\section{Total expenses direct incomes order A: 16500,00 RON \\ Total expenses direct incomes order B: 5050,00 RON}

\section{RON:}

c) Expenses with equipment damping on the direct manufacturing section, a total amount of 1155

The expenses with the equipment damping on the three sections in which the A and B order were produced summed up 1155 RON. Taking into account that these expenses cannot be deducted only from one order, because both orders were produced in the same month in the three sections, they

are distributed as indirect expenses for our orders, according to the direct salaries of the direct productive staff, using a K coefficient calculated as follows:

$$
\mathrm{K}=\frac{\text { Total section damping expenses at month level }}{\text { Total incomes of direc productive workers and taxes }}=\frac{1155}{21550}=0,053596
$$

The calculation of the amount of expense with damping to be distributed on each and every order is done by multiplying the total indirect expenses on each order to the calculated $\mathrm{K}$ coefficient, therefore:

A order distribution: $16500 * 0,053596=884,33 \mathrm{RON}$

B order distribution: $5050 * 0,053596=207,67 \mathrm{RON}$

3. Registering the depreciation costs of the installations in the sections:

923 „Indirect expenses” = 901 ,Internal settlements concerning expenses”

923-A

901-A

$\underline{1155,00}$

923-B

901-B

884,33

270,67

\section{d) Expenses with the TESA incomes}

The expenses with the TESA incomes which may be distributed on the two orders are in total amount of 4500 RON. They are distributed according to the direct incomes using the following calculus:

$$
\mathrm{K}=\frac{\text { Total TESA incomes distributed on orders }}{\text { Total incomes of direct productive workers }}=\frac{4500}{21550}=0,2088
$$

The distribution on order is made by multiplying the total indirect expenses to the incomes per each order to the $\mathrm{K}$ coefficient calculated as follows:

A order distribution: $16500 * 0,208816=3445,48 \mathrm{RON}$

B order distribution: $5050 * 0,2088=1054,52 \mathrm{RON}$

\section{Registering the expenses with TESA incomes:}

$$
\begin{array}{ccc}
923 \text { „Indirect expenses" }=901, \text {,Internal settlements concerning expenses” } & \underline{4500,00} \\
923-\mathrm{A} & 901-\mathrm{A} & 3445,48 \\
923-\mathrm{B} & 901-\mathrm{B} & 1054,52
\end{array}
$$

e) Registering the general administration expenses in total amount of $1050 \mathrm{RON}$

The same procedure of distributing the administration expenses per order is maintained and is made by

$$
\mathrm{K}=\frac{\text { Total administration expenses at month level }}{\text { Total incomes of direct productive workers }}=\frac{1050}{21550}=0,048724
$$

multiplying the total indirect expenses with incomes per each order to $\mathrm{K}$ calculated coefficient, therefore:

A order distribution: $16500 * 0,048724=803,95 \mathrm{RON}$

B order distribution: $5050 * 0,048724=246,05 \mathrm{RON}$ 
4. Registering the general administration expenses:

$\begin{array}{ccr}924, \text { "Administration expenses” }= & 901 \text { „Internal settlements concerning expenses” } & 1050,00 \\ 924-\mathrm{A} & 901-\mathrm{A} & 803,95 \\ 924-\mathrm{B} & 901-\mathrm{B} & 246,05\end{array}$

order.

\section{f) Registering selling expenses in amount of 15000 RON}

In this case also, the same procedure of distributing the selling expenses is maintained per each

$$
\mathrm{K}=\frac{\text { Total selling expenses at month level }}{\text { Total incomes of direct productive workers }}=\frac{15000}{21550}=0,696056
$$

A order distribution: $16500 * 0,696056=11484,93 \mathrm{RON}$

B order distribution: $5050 * 0,696056=3515,07 \mathrm{RON}$

\section{Registering the selling expenses:}

925 ,Selling expenses” = 901 „Internal settlements concerning expenses”

$\underline{15000,00}$

925-A 901-A

11484,93

925-B

901-B

3515,07

\section{g) Registering the production at default cost}

Based on the historical data, a production ante calculus has been made, which resulted in a complete commercial cost of $2900 \mathrm{RON}$ for York wardrobe and 450 for York night stand. As a consequence, the orders have been registered at an ante calculated cost of:

Order A (York Wardrobe): 20 x $2900=58000$ RON

Order B (York Night Stand): 50 x $450=22500$ Ron

\section{Registering the obtained production at ante calculated cost}

931 „Cost of obtained production” = 902 „Internal settlements concerning production”

80500,00

931-A

902-A

58000,00

931-B

902-B

22500,00

h) Allocation of indirect, general and selling expenses on basic activity:

8.1 Allocation of indirect expenses:

921 „Expenses of basic activity” = 923 „Production indirect expenses”

921-A

923-A

8.2 Allocation of general administration expenses:

921 „Expenses of basic activity” = 924 „General administration expenses” 
8.3 Allocation of selling expenses:

921 „Expenses of basic activity” = 925 ,Selling expenses”

15000,00

921-A

925-A

11484,93

921-B

925-B

3515,07

\section{i) Settlement of obtained production at real cost:}

We observe that there are small differences between the ante calculated and real price. The price given in ante calculus was $2900 \mathrm{RON}$ for the York Wardrobe and $450 \mathrm{RON}$ for York Night Stand. Therefore the order A (York Wardrobe) has been registered at an ante calculated price $58000 \mathrm{RON}$ and the B order (York Night Stand): 50 x $450=22500 \mathrm{RON}$. The real cost, which results from post calculus on the product unit is 2892,93 RON and 471,13 RON.

\section{Settlement for real cost}

902 „Internal settlements concerning $=921$ „Expenses of basic activity” The obtained production"

$$
\begin{array}{ll}
902-\mathrm{A} & 921-\mathrm{A} \\
902-\mathrm{B} & 921-\mathrm{B}
\end{array}
$$

\section{$\underline{81415,00}$}

57857,69

23556,31

\section{j) Registering the price differences}

Price differences will be registered as follows:

York Wardrobe: 2900-2892,93 = 7,07 RON favorable difference York

Night Stand: 450-471,13 = 21,13 RON unfavorable difference

Multiplying to the quantities per each order, we obtain the settlement for price difference:

10.1 Settlement of price difference:

903, „Internal settlements concerning = 902 „Internal settlerments concerning

$\underline{915,00}$

Price differences"

obtained production"

903-A

902-A

$-141,40$

903-B

902-B

1056,40

10.2 Accounts closure:

901 ,internal settlements concerning expenses” =

$\%$

$\underline{81415,00}$

931 „Cost of obtained production”

80500,00

903 „Internal settlements concerning

915,00

Price differences"

Table 1. Central statement of expenditure on the two orders

\begin{tabular}{|c|c|r|r|r|r|r|}
\hline \multirow{2}{*}{$\begin{array}{c}\text { NR. } \\
\text { CRT }\end{array}$} & EXPENDITURE & \multicolumn{2}{c|}{ ORDER A } & \multicolumn{2}{c|}{ ORDER B } & \multirow{2}{*}{ TOTAL } \\
\cline { 3 - 6 } & CATHEGORY & UNIT. & VALOARE & UNIT. & VALOARE & \multicolumn{1}{c|}{ VALUE } \\
\hline 1 & Total of direct expenses & 2062,00 & 41240,00 & 369,40 & 18470,00 & 59710,00 \\
\hline 2 & Total indirect expenses & 216,49 & 4329,81 & 26,50 & 1325,19 & 5655,00 \\
\hline \multicolumn{2}{|c|}{$\begin{array}{c}\text { Production cost } \\
\text { General administration } \\
\text { expenses }\end{array}$} & 2278,49 & 45569,81 & 395,90 & 19795,19 & 65365,00 \\
\hline 4 & Selling expenses & 40,20 & 803,95 & 4,92 & 246,05 & 1050,00 \\
\hline \multicolumn{2}{|c|}{ Commercial complete cost } & 2892,93 & 57858,69 & 471,13 & 23556,31 & 81415,00 \\
\hline
\end{tabular}

Source: author's own projection 
For verification the accounts' situation has been made, which is as follows:

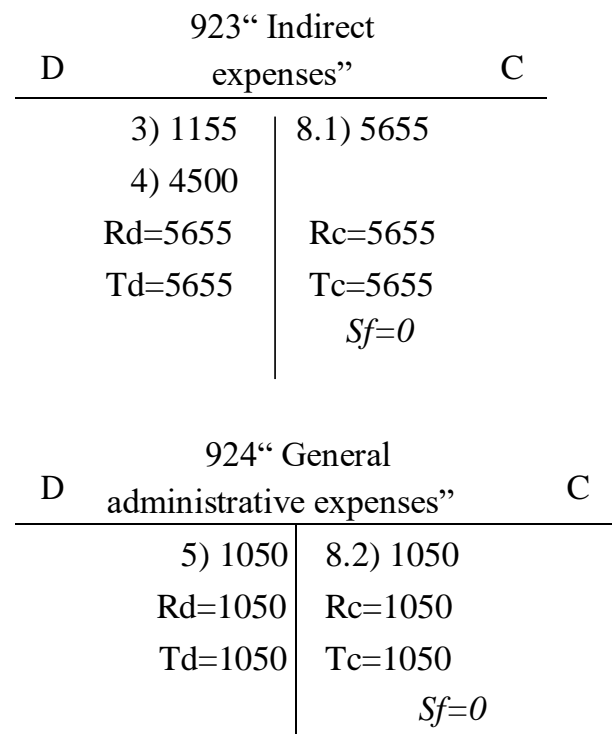

\begin{tabular}{r|ll} 
D $\quad$ 925“ Selling expenses” & C \\
\hline 6) 15000 & $8.3) 15000$ \\
Rd=15000 & $\mathrm{Rc}=15000$ \\
Td=15000 & $\mathrm{Tc}=15000$ \\
& $\mathrm{Sf}=0$
\end{tabular}

921“" Expenses of
basic activity”
1) 38160
9) 81415

2) 21550

8.1) 5655

8.2) 1050

$8.3)$

15000

$\mathrm{Rd}=81415 \quad \mathrm{Rc}=81415$

$\mathrm{Td}=81415 \quad \mathrm{Tc}=81415$

$S f=0$

\begin{tabular}{|c|c|}
\hline $\begin{array}{r}931^{\prime \prime} \text { Cost } \\
\text { prod }\end{array}$ & $\begin{array}{l}\text { of obtained } \\
\text { ction" }\end{array}$ \\
\hline 7) 80500 & 10.2) 80500 \\
\hline $\mathrm{Rd}=80500$ & $\mathrm{Rc}=80500$ \\
\hline $\mathrm{Td}=80500$ & $\begin{array}{c}\mathrm{Tc}=80500 \\
S f=0\end{array}$ \\
\hline
\end{tabular}

901“ Internal

settlements concerning

D

\begin{tabular}{l|l} 
10.2) 81415 & 1) 38160 \\
& 2) 21550 \\
& 3) 1155 \\
& 4) 4500 \\
& 5) 1050 \\
& 6) 15000 \\
& 7) 15000 \\
$\mathrm{Rd}=81415$ & $\mathrm{Rc}=81415$ \\
$\mathrm{Td}=81415$ & $\mathrm{Tc}=81415$ \\
& $S f=0$
\end{tabular}

902 "Internal settlements concerning the obtained

\begin{tabular}{r|l} 
D & \multicolumn{2}{|c}{ production" } & C \\
\hline 9) 81415 & 7) 80500 \\
& 10.1) 915 \\
$\mathrm{Rd}=81415$ & $\mathrm{Rc}=81415$ \\
$\mathrm{Td}=81415$ & $\mathrm{Tc}=81415$ \\
& $S f=0$
\end{tabular}

903 "Internal settlements concerning price

D differences" C

$$
\begin{array}{r|l}
\text { 10.1) } 915 & 10.2) 915 \\
\mathrm{Rd}=915 & \mathrm{Rc}=915 \\
\mathrm{Td}=915 & \mathrm{Tc}=915 \\
& S f=0
\end{array}
$$

\section{Conclusions}


From analyzing the specialty literature in this paper it results that there are important preoccupations for the studying of managerial accounting. No matter of the management method we can refer to, there is unanimous accepted that the main purpose of the managerial accounting is the one of sustaining the internal decisions of the board of directors, therefore stepping out of the sphere and specific of financial accounting.

As a conclusion on the first research objective, we consider that it has been reached. As a result of revising the specialty literature and of legislation in this domain, the reporting of the system of management accounting has been presented in the national legislation, as well as placing the method of calculation per order among the methods used by managerial accounting. There have been presented eventual limits from the specialty literature as well as the method of calculating the costs from a theoretical point of view.

Concerning the central research objective, respectively making the case study concerning the application of the managing method of costs per order in the furniture industry, we also consider that as a result of the effected research, it has been fulfilled. The entity's production flux was proved and presented, production's organization as well as the accounting in management accounting. In our case from the financial accounting have been taken over, registered and distributed on cost categories, expenses with: raw materials, direct labor, indirect, administrative and selling expenses. After each expense was registered in managerial accounting, on every account it was followed the accounting closure, therefore ensuring a complete cycle of following.

Even though the method per order is used in the industry for a long time, being considered in the specialty literature as being old fashioned, we consider that the method of managing costs per order is useful and entirely efficient, especially in the furniture industry in Romania. The industry's overall structure and its specific have progress to do concerning the computerization capacity, investments in systems like Enterprise Resource Planning (ERP), but the implementation of cost calculating method at the level of most entities in the sector may add special value in the sector of furniture industry in Romania.

\section{Acknowledgements}

This work is supported by project POCU 125040, entitled "Development of the tertiary university education to support the economic growth - PROGRESSIO", co-financed by the European Social Fund under the Human Capital Operational Program 2014-2020

\section{References}

1. Briciu Sorin, 2011. Management Accounting - University Course, Alba Iulia

2. Briciu Sorin, Sorinel CăpuȘneanu, Letiția M. Rof, Dan Topor, 2010. Accounting and Management Control - Tools for Evaluating the Entity's Performance, Alba Iulia, Aeternitas Pbs.

3. CăpuȘneanu Sorinel, Briciu Sorin, 2011. Analysing the Possibility of Organising the Management Accounting through Target Costing Method within the Entities in Romania, in Theoretical and Applicable Economy, volume XVIII, no. 9(256), pp. 53-54, online on http://store.ectap.ro/articole/638_ro.pdf accessed on 01.05.2019.

4. Horngren Charles, Srikant Datar, George Foster, 2006. Cost Accounting, a Managerial Approach, XI ${ }^{\text {th }}$ edition, Bucharest, ARC Pbs

5. Accounting Law no. 82/1991 republished in Romania's Official Monitory, $1^{\text {st }}$ Part, no. 629 from the $26^{\text {th }} \quad$ of August 2002. https://static.anaf.ro/static/10/Anaf/legislatie/Legea_contabilitatii.htm accessed on 01.05.2019.

6. Mărginean Radu, 2013. The Cost Management by Applying the Standard Costing Method in the Furniture Industry, in SEA-Practical Application of Science, Volume I, Issue 1(1), 97-105, http://seaopenresearch.eu/Journals/articles/SPAS_1_10.pdf, accessed on 01.05.2019.

7. Mărginean Radu, 2015. Complex Capitalization of Accounting Information for Analizing the Economical Performance, in the Furniture Industry, Doctoral Dissertation, Alba-Iulia.

8. Mărginean Radu, Țepeș Bobescu Anamaria, 2014. The Cost control by Applying the Target Costing Method in the Construction Industry-Case Study, in SEA-Practical Application of Science, Volume II, Issue 1(3)/2014, 348-357, online on http://www.sea.bxb.ro/Article/SEA_3_41.pdf accessed at 
01.05.2019.

9. OMFP 1802/2014, https://static.anaf.ro/static/10/Anaf/legislatie/OMFP_1802_2014.pdf, accessed on 01.05.2019.

10. Precizări privind unele măsuri referitoare la organizarea şi conducerea contabilităţii de gestiune, aprobate prin Ordinul M.F.P. nr. 1826/2003, publicate în Monitorul Oficial al României nr. 23/2004, http://www.contaconta.ro/miscellaneous/1.085_miscellaneous_contabilitate_files\%201.085_.pdf, accessed on 01.05.2019.

11. Standardul Internațional de Contabilitate 1(IAS 1) Prezentarea situaţiilor financiare, https://circabc.europa.eu/d/d/workspace/SpacesStore/2eaa0faf-25a4-478a-b66d52b86851155a/IFRS\%20Consolidated\%20annex_ro.pdf, accesat la 01.05.2019.

12. Şendroiu Cleopatra, Aureliana Geta Roman, Costantin Roman, 2006. Metoda standard-cost în varianta standard-cost unic, direcţie de perfecționare a contabilităţii de gestiune şi a calculaţiei costurilor în industria de maşini şi echipamente, Economie Teoretică și Aplicată, no. 7(502), 81-84, http://store.ectap.ro/articole/125.pdf, accessed on 01.05.2019. 